\title{
Improving Teacher Performance in Developing Teaching Materials Through Academic Supervision as an Effort to Improve Academic Quality in Schools
}

\author{
Mahsun Alwa'id \\ Madrasah Aliyah Negeri 1 Semarang \\ Email:mahsunalwaid@rocketmail.com
}

\begin{abstract}
An important problem that is often faced by teachers in learning activities is choosing or determining appropriate learning materials or teaching materials in order to help students achieve competence. This is due to the fact that in the curriculum or syllabus, teaching materials are only written in outline in the form of "subject material". It is the teacher's job to describe the subject matter so that it becomes a complete teaching material. In addition, how to use teaching materials is also a problem. The intended use is how to teach it from the teacher's point of view, and how to learn it from the student's point of view. The purpose of this school action research (PTS) is to find out the extent to which the coaching of the Madrasah Principal improves the performance of teachers in choosing teaching materials. In this school action research (PTS), it was carried out in 3 cycles, from the results of the actions taken it was proven to be able to improve teacher performance by achieving ideal standards. From $64.47 \%$ in the first cycle, it could increase to $74.59 \%$ in the second cycle, and the second cycle. to III $83.29 \%$. The results of this action research indicate that coaching through the academic supervision of the Madrasah Head can improve teacher performance in choosing teaching materials at MAN 1 Semarang, Semarang Regency.
\end{abstract}

Keywords: Teacher Performance, Teaching Materials, Academic Supervision, Quality Achievement

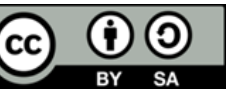

Copyright (C) 2021 The Author(s)

This is an open access article under the CC BY-SA license.

\section{INTRODUCTION}

An important problem that teachers often face in learning activities is choosing or determining the right learning materials or teaching materials in order to help students achieve competence. This is due to the fact that in the curriculum or syllabus, teaching material is only written in outline in the form of "subject matter". It is the teacher's job to describe the subject matter so that it becomes a complete teaching material. In addition, how to use teaching materials is also a problem. Utilization is how to teach it reviewed from the teacher's side, and how to learn it on the part of students.

With regard to the selection of this teaching material, in general the problem in question includes the way of determining the type of material, depth, scope, order of presentation, treatment (treatment) of learning materials, etc. Another problem related to teaching materials is choosing the source where the teaching material is obtained. There is a tendency for the source of teaching materials to be focused on books. There are many sources of teaching materials other than books that can be used. Books do not have to be one of a kind and do not 
Alwa'id. | Improving Teacher Performance in Developing Teaching Materials Through Academic Supervision as an Effort to Improve Academic Quality in Schools

have to change as often as happened during this time. Various books can be selected as a source of teaching materials.

Including the problems that teachers often face with regard to teaching materials are teachers giving teaching materials or learning materials too broad or too little, too deep or too shallow, the order of improper presentation, and the type of teaching material material that does not match the competence that the student wants to achieve. With regard to source books often occur every semester change or change of year book change.

In connection with that, it is necessary to prepare signs of selection and utilization of teaching materials to help teachers to be able to choose learning materials or teaching materials and utilize them appropriately. The signs in question include the concepts and principles of learning material selection, determination of scope, order, criteria and steps of selection, treatment / utilization, and source of learning materials.

When is the learning material or teaching material determined or selected? In the framework of the implementation of learning, including competency-based learning, teaching materials are selected after the identity of the subjects, competency standards, and basic competencies are determined. As is known, learning development measures in accordance with KTSP, among others, first determine the identity of the subject. After that determine the Core Competencies,Basic Competencies, learning materials, learning strategies / learning experiences, achievement indicators, etc. After the points of learning material are determined, the material is then outlined. The description of the learning material can contain key concepts that must be studied by students or in the form of a complete description as contained in textbooks.

As outlined above, learning materials (teaching materials) are one component of the learning system that plays an important role in helping students achieve basic competency and competency standards. Broadly speaking, teaching materials or learning materials contain knowledge, skills, and attitudes or values that students must learn.

Learning materials need to be selected appropriately so that they can help students in achieving basic competency and competency standards. Problems that arise with regard to the selection of learning materials regarding the type, scope, sequence, treatment (treatment) of learning materials and the source of teaching materials. The type of learning material needs to be identified or determined appropriately because each type of learning material requires different strategies, media, and ways of evaluating. The scope or scope and depth of learning materials need to be considered so that it is not less and no more. Sequence (sequence) needs to be considered so that learning becomes runtut. Treatment (how to teach / convey and learn) needs to be selected precisely so as not to teach or learn it (e.g. it needs clarity whether a material should be memorized, understood, or applied).

The term Performance can be translated into perfomance or performance, meaning the ability that a person displays to his work at the place where he works. Teacher performance is an essential performance of the success of a job. Therefore a consistent performance for each individual needs to be created so that the institution's goals can be achieved optimally.

Instructional materials broadly consist of knowledge, skills, and attitudes that must be learned by students in order to achieve predetermined competency standards. In detail, these types of learning materials consist of knowledge (facts, concepts, principles, procedures), skills, and attitudes or values.

There are several principles that need to be considered in the preparation of teaching materials or learning materials. The principles in the selection of learning materials include the principles of relevance, consistency, and adequacy.

The principle of relevance means interconnectedness. Learning materials should be relevant or have something to do or have to do with the achievement of basic competency and competency standards. For example, if the expected competence is mastered by students in the 
Alwa'id. | Improving Teacher Performance in Developing Teaching Materials Through Academic Supervision as an Effort to Improve Academic Quality in Schools

form of memorizing facts, then the learning material taught must be in the form of facts or rote memorization.

The principle of consistency means keajegan. If the basic competencies that must be mastered by students of four kinds, then the teaching materials that must be taught must also include four kinds. For example, the basic competence that must be mastered by students is the operation of numbers that include addition, subtraction, multiplication, and division, then the material taught must also include addition techniques, subtraction, multiplication, and division.

The principle of adequacy means that the material taught should be adequate enough in helping students master the basic competencies taught. The material should not be too little, and it should not be too much. If too little will be less helpful to achieve basic standards of competence and competence. Conversely, if too much will be a waste of unnecessary time and energy to learn it.

Before carrying out the selection of teaching materials, first it is necessary to know the criteria for selection of teaching materials. The main criteria for the selection of teaching materials or learning materials are basic competency and competency standards. This means that the learning materials chosen to be taught by teachers on the one hand and must be studied by students on the other should contain materials or teaching materials that really support the achievement of basic competency and competency standards. In other words, the selection of teaching materials should refer to or refer to competency standards.

Broadly speaking, the steps of teaching material selection include first identifying the aspects contained in the basic competency and competency standards that are references or references to the selection of teaching materials. The next step is to identify the types of teaching materials. The third step is to choose teaching materials that are appropriate or relevant to the basic competency and competency standards that have been identified earlier. The last is to choose the source of the teaching material.

\section{METHOD}

This research uses Classroom Action Research (CAR). CAR is an observation of learning activities in the form of an action that is deliberately raised and occurs in a large class together. The action is given by the teacher or with direction from the teacher carried out by students (Arikunto, 2008: 3). So according to the type of research used, namely action research, research begins with planning action (planning), applying action (action), observing and evaluating the process and achievement of action (observation and evaluation), and reflecting (reflective) (Supardi, 2008: 104).

Subjek in this study is Guru MAN 1 Semarang Regency 2019/2020.

The number of teachers who are the objects in the study is presented in the following Table:

TABLE 1

LIST OF RESEARCH RESPONDENTS

\begin{tabular}{|c|c|c|}
\hline No. & Teacher's Name & Teaching classes \\
\hline 1 & Dra. Hj. Isni Alfiyah & Fiqh \\
\hline 2 & Dra. Sumaryani & Biology \\
\hline 3 & Dra. Siti Rahayu & English \\
\hline 4 & Dra. Hj. Istiqomah & Moral creed \\
\hline 5. & Dra. Hj. Elmufida & Jurisprudence \\
\hline 6. & Dra. Tutik Hijaiyah & Mathematics \\
\hline 7. & Yuli Afifah, S.Pd. & Indonesian \\
\hline 8. & Helina Pancawardhani, S.Pd. & Chemistry \\
\hline
\end{tabular}


Alwa'id. | Improving Teacher Performance in Developing Teaching Materials Through Academic Supervision as an Effort to Improve Academic Quality in Schools

\begin{tabular}{cll}
\hline 9. & Taufikurahman, S.Ag. & Arabic \\
10. & Hj. Rosidah, S.Pd, M.Pd.I & Geophysics \\
11. & Prapti Kusuma Dewi, S.Pd. & PKn \\
12. & Eka Nurmaya, S.Pd. & Physics \\
13. & Ani Ma'rifah, S.Pd. & History \\
14. & Siti Hasanah, S.Ag. & SKI \\
15. & Nina Triyanawati, S.Pd. & Economics \\
16. & Budiyanto, S.Pd. & Sociology \\
17. & Laela Musdzalifah, SPd. & Cultural Arts \\
\hline
\end{tabular}

Data Source: MAN 1 Semarang Semarang Regency year of study 2019/2020. School Action Research Plan (PTS) according to Arikunto, Suharsimi, 2007;74 is like the following image:

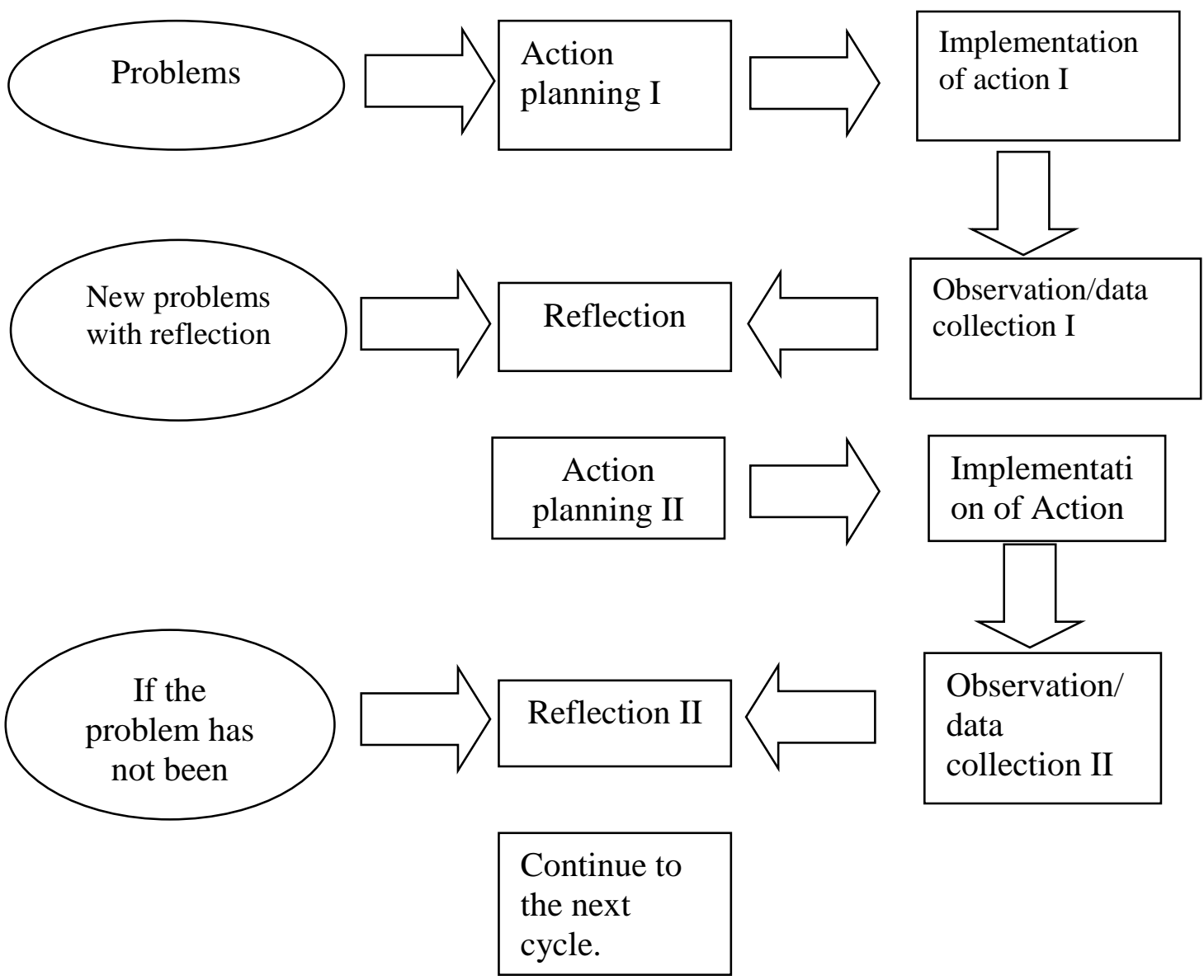

In theform of a plan in the form of a draft of actions that explain what, why, when, where, by whom, and how the action is carried out. In PTS where researchers and teachers are different people, in the stage of drafting there must be an agreement between the two. The design must be done jointly between the teacher who will take action with the researcher who will observe the process of the course of action. This is to reduce the element of observer subjectivity and the quality of careful observations made.

At the action stage, the draft action has of course previously been trained to the executor of the action (teacher) to be applicable in the classroom in accordance with the scenario. The scenario of the action must be properly executed and appear reasonable. 
Alwa'id. | Improving Teacher Performance in Developing Teaching Materials Through Academic Supervision as an Effort to Improve Academic Quality in Schools

At the observation or observation stage actually goes along with the time of implementation. Observations are made at the time the action is progressing, so, both take place at the same time.

At this stage the researcher (or teacher if he acts as a researcher) makes observations and records all the things that are necessary and occur during the implementation of the action. This data collection is carried out using a form of observation / assessment that has been arranged, including careful embedding of the implementation of action scenarios over time and their impact on student learning processes and outcomes.

The last stage is reflection, it is intended to thoroughly review the actions that have been done, based on the data that has been collected, then evaluated to improve the next action.

Reflection in PTS includes analysis, synthesis, and assessment of the results of observations of actions taken. If there is a problem from the reflection process then the process of review through the next cycle which includes activities: re-planning, re-action, and re-observation of the problem can be resolved (Hopkins, 1993).

In this School Action research, the variable that will be studied is the improvement of teacher performance in the development of teaching materials through the academic supervision of madrasah heads in an effort to improve the achievement of Madrasah Quality.

The data sources in this study come from two sources, namely teachers (diper obtained data on improving teacher performance in the development of teaching materials)and madrasah heads (diper obtained data on the application of academic supervision of madrasah heads).

Data collection techniques using Observation and Tests. School action research conducted in three cycles is considered successful if there is an increase in teacher performance in the development of teaching materials reaching $85 \%$ (Schools studied) has achieved completion with an average score of 75. means that it has met ideal expectations as required in school-based management (MBS) with an ideal standard of at least 75 .

In data analysis the techniques used uantitative and qualitative. Quantitative techniques are used to calculate the magnitude of the improvement in teacher performance in the development of teaching materials by using percentage (\%). Qualitative techniques are used to provide an overview of research results in a way; data reduction, descriptive presentation, and withdrawal of conclusions.

\section{RESEARCH RESULTS}

\section{CYCLE 1}

In the planning stage, researchers prepare coaching tools in the form of learning planning, standardized learning implementation and other supporting teaching tools. The implementation of coaching activities for cycle I was held on January 22 to 29, 2020, at MAN 1 Semarang Semarang Regency in the $2019 / 2020$ school year with a teacher count of 17 people. In this case the researcher acts as the head of the madrassa. The coaching process refers to the coaching plan that has been prepared, and implemented at the time of the teaching and learning process.

Observation (observation) is carried out in conjunction with the implementation of teaching and learning. At the end of coaching is given an assessment test I with the aim to find out the improvement of teacher performance in the development of teaching materials that have been done. The data of research results in cycle $\mathrm{l}$. is as in the following table: 
Alwa'id. | Improving Teacher Performance in Developing Teaching Materials Through Academic Supervision as an Effort to Improve Academic Quality in Schools

Table 2

Table distribution of Values of Teacher Performance Improvement in The Development of Teaching Materials through Academic Supervision of Madrasah Heads in Cycle I

\begin{tabular}{|c|c|c|c|c|}
\hline \multirow{2}{*}{ No. } & \multirow{2}{*}{ Name } & \multirow{2}{*}{ Score } & \multicolumn{2}{|c|}{ Information } \\
\hline & & & Done & Not Complete \\
\hline 1 & Dra. Hj. Isni Alfiyah & 70 & $v$ & \\
\hline 2 & Dra. Sumaryani & 56 & & v \\
\hline 3 & Dra. Siti Rahayu & 56 & & $v$ \\
\hline 4 & Dra. Hj. Istiqomah & 58 & & v \\
\hline 5. & Dra. Hj. Elmufida & 74 & $v$ & \\
\hline 6. & Dra. Tutik Hijaiyah & 58 & & $v$ \\
\hline 7. & Yuli Afifah, S.Pd. & 70 & $v$ & \\
\hline 8. & Helina Pancawardhani, S.Pd. & 60 & & v \\
\hline 9. & Taufikurahman, S.Ag. & 70 & $v$ & \\
\hline 10. & Hj. Rosidah, S.Pd, M.Pd.I & 70 & $v$ & \\
\hline 11. & Prapti Kusuma Dewi, S.Pd. & 58 & & $v$ \\
\hline 12. & Eka Nurmaya, S.Pd. & 62 & & v \\
\hline 13. & Ani Ma'rifah, S.Pd. & 64 & & $v$ \\
\hline 14. & Siti Hasanah, S.Ag. & 66 & & v \\
\hline 15. & Nina Triyanawati, S.Pd. & 70 & $v$ & \\
\hline 16. & Budiyanto, S.Pd. & 62 & & v \\
\hline 17. & Laela Musdzalifah, SPd. & 72 & $v$ & \\
\hline Total $\mathbf{n}$ & Imber & 1096 & & \\
\hline Indivic & al Maximum Score & 100 & & \\
\hline Group & laximum Score & 1700 & & \\
\hline
\end{tabular}

From the table above it can be explained that with coaching through academic supervision the head obtained the average score is $64.47 \%$ or there are 7 people out of 17 teachers have been completed. The results showed that in the first cycle as a whole was not completed, because teachers who obtained a score of $\geq 70$ only $41.18 \%$ less than the desired completion percentage of $85 \%$. This is because teachers still feel new and do not understand what teachers mean and use by applying coaching through academic supervision.

In the implementation of coaching activities obtained information from observations are the head of madrasah is less good in motivating teachers and in conveying the purpose of coaching, madrassa heads are less good in managing time and teachers are less enthusiastic during coaching. The implementation of construction activities in cycle I is still lacking, so there needs to be revisions to be done in the next cycle.

\section{CYCLE II}

In this planning, researchers prepare a coaching tool consisting of a coaching plan 2, formative test questions II and other supporting coaching tools. The implementation of coaching activities for cycle II was held on February 5 to 12, 2020 at MAN 1 Semarang Semarang Regency in the 2019/2020 school year. In this case the researcher acts as the Head of the madrassa. The 
Alwa'id. | Improving Teacher Performance in Developing Teaching Materials Through Academic Supervision as an Effort to Improve Academic Quality in Schools

coaching process refers to the coaching plan by paying attention to revisions to cycle I, so that errors or deficiencies in cycle I are not repeated in cycle II. Research of the school's actions is carried out in accordance with the procedures of the coaching plan and the implementation of coaching is carried out during the teaching and learning process. At the end of the coaching process the teacher is given a formative test II with the aim to find out the success rate in doing coaching. The instrument used is the formative test II. The data of research results in cycle II is as follows:

Table 3:

Table Distribution Of Teacher Performance Improvement Values in The Development of Teaching Materials through Academic Supervision of Madrasah Heads in Cycle II

\begin{tabular}{|c|c|c|c|c|}
\hline \multirow{2}{*}{ No. } & \multirow{2}{*}{ Name } & \multirow{2}{*}{ Score } & \multicolumn{2}{|c|}{ Information } \\
\hline & & & Done & Not Complete \\
\hline 1 & Dra. Hj. Isni Alfiyah & 80 & $\mathrm{v}$ & \\
\hline 2 & Dra. Sumaryani & 68 & & $\mathrm{v}$ \\
\hline 3 & Dra. Siti Rahayu & 74 & $\mathrm{v}$ & \\
\hline 4 & Dra. Hj. Istiqomah & 68 & & $v$ \\
\hline 5. & Dra. Hj. Elmufida & 80 & 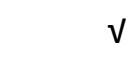 & \\
\hline 6. & Dra. Tutik Hijaiyah & 68 & & $\mathrm{v}$ \\
\hline 7. & Yuli Afifah, S.Pd. & 80 & $\mathrm{v}$ & \\
\hline 8. & Helina Pancawardhani, S.Pd. & 74 & v & \\
\hline 9. & Taufikurahman, S.Ag. & 80 & v & \\
\hline 10. & Hj. Rosidah, S.Pd, M.Pd.I & 78 & v & \\
\hline 11. & Prapti Kusuma Dewi, S.Pd. & 76 & $v$ & \\
\hline 12. & Eka Nurmaya, S.Pd. & 68 & & $\checkmark$ \\
\hline 13. & Ani Ma'rifah, S.Pd. & 68 & & $v$ \\
\hline 14. & Siti Hasanah, S.Ag. & 70 & v & \\
\hline 15. & Nina Triyanawati, S.Pd. & 80 & v & \\
\hline 16. & Budiyanto, S.Pd. & 74 & v & \\
\hline 17. & Laela Musdzalifah, SPd. & 82 & $\mathrm{v}$ & \\
\hline \multicolumn{2}{|c|}{ Total Number } & 1268 & & \\
\hline \multicolumn{2}{|c|}{ Individual Maximum Score } & 100 & & \\
\hline \multicolumn{2}{|c|}{ Group Maximum Score } & 1700 & & \\
\hline
\end{tabular}

From the table above obtained the average score obtained by teachers is $74.59 \%$ and teacher performance improvement is $70.59 \%$ or there are 12 people out of 17 teachers who have completed. These results show that in cycle II this coaching results through academic supervision have improved slightly better than cycle I. The improvement in teacher performance is because the head of the madrassa has informed that each end of coaching will be held an assessment so that at the next meeting the teacher is more motivated to improve his performance. In addition, teachers have also begun to understand what is meant and desired by the head of madrasah in conducting coaching through academic supervision. In the implementation of coaching obtained information from observations are motivating the head of madrasah, guiding teachers in developing teaching materials, formulating conclusions / finding concepts and managing time. 
Alwa'id. | Improving Teacher Performance in Developing Teaching Materials Through Academic Supervision as an Effort to Improve Academic Quality in Schools

\section{CYCLE III}

In planning, researchers should prepare coaching tools related to learning planning in school 3, formative test questions 3 and other supporting coaching tools. The implementation of coaching activities for cycle III was held on February 19 to 26, 2020 at MAN 1 Semarang Semarang Regency 2019/2020 with a total of 17 teachers. In this case the researcher acts as the Head of the madrassa. The process of annihilation refers to the construction plan by paying attention to revisions to cycle II, so that errors or deficiencies in cycle II are not repeated in cycle III. Observation (observation) is carried out in conjunction with the teaching and learning process in schools.

At the end of the coaching process is given a formative test III with the aim to find out the success rate of the teacher in improving his performance to develop teaching materials that have been done. The instrument used is formative test III. The data on the results of research in cycle III are as follows:

Table 4

Table Distribution of Values of Improving Teacher Performance in The Development of Teaching Materials through Academic Supervision of Madrasah Heads in Cycle III

\begin{tabular}{|c|c|c|c|c|}
\hline \multirow{2}{*}{ No. } & \multirow{2}{*}{ Name } & \multirow{2}{*}{ Score } & \multicolumn{2}{|c|}{ Information } \\
\hline & & & Done & Not Complete \\
\hline 1 & Dra. Hj. Isni Alfiyah & 90 & $\mathrm{~V}$ & \\
\hline 2 & Dra. Sumaryani & 74 & $\mathrm{v}$ & \\
\hline 3 & Dra. Siti Rahayu & 80 & $v$ & \\
\hline 4 & Dra. Hj. Istiqomah & 72 & $v$ & \\
\hline 5. & Dra. Hj. Elmufida & 90 & $v$ & \\
\hline 6. & Dra. Tutik Hijaiyah & 76 & 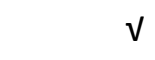 & \\
\hline 7. & Yuli Afifah, S.Pd. & 90 & v & \\
\hline 8. & Helina Pancawardhani, S.Pd. & 86 & $v$ & \\
\hline 9. & Taufikurahman, S.Ag. & 90 & v & \\
\hline 10. & Hj. Rosidah, S.Pd, M.Pd.I & 88 & $\mathrm{v}$ & \\
\hline 11. & Prapti Kusuma Dewi, S.Pd. & 84 & $\sqrt{ }$ & \\
\hline 12. & Eka Nurmaya, S.Pd. & 74 & v & \\
\hline 13. & Ani Ma'rifah, S.Pd. & 76 & $\mathrm{v}$ & \\
\hline 14. & Siti Hasanah, S.Ag. & 80 & $v$ & \\
\hline 15. & Nina Triyanawati, S.Pd. & 90 & 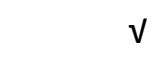 & \\
\hline 16. & Budiyanto, S.Pd. & 86 & v & \\
\hline 17. & Laela Musdzalifah, SPd. & 90 & $\sqrt{ }$ & \\
\hline \multicolumn{2}{|c|}{ Total Number } & 1416 & & \\
\hline \multirow{2}{*}{\multicolumn{2}{|c|}{ Individual Maximum Score }} & 100 & & \\
\hline & & 1700 & & \\
\hline
\end{tabular}

Based on the table above obtained a formative test average score of $83.29 \%$ and from 17 teachers have achieved completion in improving teacher performance to develop teaching materials. So in the completion group has reached $100 \%$ (including the complete category). The results in cycle III are improved better than cycle II. The improvement of coaching results in cycle III is influenced by the improvement of the ability of madrassa heads in implementing academic supervision so that teachers become more understanding of their respective duties and can improve their performance in developing teaching materials. In addition, this completion is also 
Alwa'id. | Improving Teacher Performance in Developing Teaching Materials Through Academic Supervision as an Effort to Improve Academic Quality in Schools

influenced by the cooperation of the head of the madrassa, and teachers in planning and improving theirperformance.

At the stage of reflection will be studied what has been done well and still not good in the process of construction through academic supervision. From the data that has been obtained can beexplained, among others, during theprocess of building the head of themadrasah has carried out all the construction well. Although there are some aspects that are not perfect, but the percentage of implementation for each aspect is quite large, based on observational data it is known that the teacher is active during the coaching process, the deficiencies in the previous cycles have improved and improved so that it becomes better and the results of madrasah head coaching through academic supervision in cycle III reach completion.

From the results of the analysis obtained data on the improvement of teacher performance after being given coaching through academic supervision, namely improving teacher performance in the development of teaching materials; $64.47 \%$ to $74.59 \%$ there was an increase of $=10.12 \%$, from before coaching (cycle 1 ) and after coaching by madrasah heads up to (cycle 3) $64.47 \%$ to $74.59 \%$, and from (cycle 2 ) to (cycle 3 ) there was also an increase of $83.29 \%$ $74.59 \%=8.71 \%$, so that the average increase in teacher performance in the development of teaching materials before being given coaching $41.18 \%$ rose to $100 \%$.

\section{DISCUSSION}

Through the results of this research shows that coaching through Academic supervision having a positive impact in improving teacher performance, this can be seen from the steadier understanding of teachers to the coaching delivered by madrasah heads (the development of teaching materials increased from cycles I, II, and III) which is $64.47 \%$ each; $74,59 \% ; 83.29 \%$ In cycle III the improvement of teacher performance in the development of teaching materials in groups is said to be complete / improved. AThe teacher's ktivitas in improving his performance in each cycle has increased. This has a positive impact on the achievement of Madrasah Quality, which can be shown by increasing the average value of teachers in each cycle that continues to increase. AThe most dominant madrassa heads and teachers in coaching activities are working using tools / media, listening / paying attention to the explanation of madrasah heads, and discussions between teachers and madrasah heads. So it can be said that the teacher's activities can be categorized as active.

As for the activities of the head of madrasah during coaching has carried out the steps of the coaching method through academic supervision well. This is seen from the activities of teachers that arise including the activity of creating and planning learning programs, implementing, providing feedback / evaluation / Q\&A where the percentage for the above activities is quite large.

Based on the results of the above research, the improvement of teacher performance in the development of teaching materials through academic supervision results are very good. It was seen at the first meeting of 17 teachers who were there at the time of the study was conducted the average score reached; $64.47 \%$ increased to $74.59 \%$ and in cycle 3 increased to $83.29 \%$.

From the analysis of the above data that the coaching of madrasah heads through academic supervision is effectively applied in an effort to improve teacher performance in the development of teaching materials, which means that the process of coaching madrasah heads is more successful and can improve the achievement of Madrasah Quality, especially in MAN 1 Semarang Regency, therefore it is expected that madrasah heads can carry out coaching through academic supervision on an ongoing basis. 
Alwa'id. | Improving Teacher Performance in Developing Teaching Materials Through Academic Supervision as an Effort to Improve Academic Quality in Schools

\section{CONCLUSION}

Based on the analysis of research results and discussions can be concluded that pThe use of madrasah heads in an effort to improve teacher performance in the development of teaching materials through academic supervision shows improvement in each round (Cycle)., aKtivitas in coaching activities shows that all teachers can improve their performance well in every aspect., pimprovement of the quality of the school by the head of the madrasah through through Academic supervision This shows an increase in each round. and aTeacher activity shows that academic supervision training activities are useful and can help teachers to younger understand the concept of teacher roles and functions so that the improvement of Madrasah Quality achievement can run well, and thus improve the achievement of Madrasah Quality can be improved.

\section{REFERENCE}

Arif, Syamsul, "Academic Supervision in Improving Teacher Skills in Designing IT-Based Teaching Materials Through Guided Training, "Jurnal An-Nahdhah 11 (2017).

Coimbra, Maria de Nazaré Castro Trigo, "Supervision and Evaluation:Teachers" Perspectives", International Journal of Humanities and Social Science Vol. 3 No. 5 (2013).

Ahmad, La Ode Ismail, "The Concept of Teacher Performance Assessment and the Factors That Affectlt", Jurnal Idaarah vol. 1 no.1 (2017).

Murniyati et al.,"Implementation of Academic Supervision of School Superintendents as An Effort to Improve TeacherProfessionalism", Journal of Management, Leadership, and Supervision of Education Vol. 3 No. 1 (2018).

Suripto, "Efforts to Improve Teacher Performance in Learning Through Academic Supervision at Dabin Elementary School I UPTD Education Bayat Klaten District In 2015, "Supervisor of UPTD Bayat Subdistrict: Magistra Journal 95 (2015).

Yusnindar. "Leadershipof Madrasah Head in Improving Teacher Performance on MAN Model Banda Aceh." Journal of Scientific Didactics: Scientific Media Education and Teaching vol 14, no. No. 2 (2014).

Suto Prabowo and Dyah Satya Yoga. "Supervising Class Visits as an Effort to Foster Professional Teachers SLTP / SLTA." Journal of Social Humanities 9, no. 1 (2016): 102.

Melkyanus kaleka, Natalia Nata. "Improving Teacher Performance Through Academic Supervision of Principals With An Individualized Approach at SMPN 7 Nangapanda." Journal of Physics Education Vol 4, no. 1 (2020).

John, Dewey. "Understandingthe Duties and Functions of the Principal"2021. Retrieved January 13, 2021. https://www.silabus.web.id/kepala-sekolah/

Riski, Aulia. "AcademicSupervision of The Principal,"2019. Accessed November 9, 2020. https://doi.org/10.31227/osf.io/8whvi

Iskandar, Uray. "Headmaster's Leadership in Improving Teacher Performance." Jurnal Visi IImu Pendidikan Vol 5, no. 1 (2013).

Happy Fitria, Yessi Fitriani, Ariyadi Raberi. "Thelnfluence of The Supervision of the Principal and the Role of the School Committee on Teacher Performance in Sanga Village State ElementarySchool." Journal of Al-Qiyam Vol 1, no. 2 (2020).

Hamid, Abdul. "TheEffect of the Working Climate on the Performance of Madrasah Teachers Ibtidaiyah State Bandar Lampung City." AlBayan UIN Raden Intan 6, no. 1 (2014).

Bowo. "TheLeadership Role of the Principal as a Supervisor in Improving Teacher Competence in State High School 1 Ngronggot Nganjuk Regency in 2020." Journal of Dharma Education Vol 15, no. 2 (2020).

Baharuddin. Headmaster's Leadership in the Era of EducationalAutonomy. Journal of Al Harokah, Malang: State University of Malang. Volume 63 Number 1 January-April (2006): 19.

Nopembri, A. Dedi. "TheFunction of the Principal in Improving Teacher Performance",Journal of EducationManager, Lubuklinggau Utara I: Lubuklinggau City Education Office. Volume 9 Number 3 (2015): 394-40 
Alwa'id. | Improving Teacher Performance in Developing Teaching Materials Through Academic Supervision as an Effort to Improve Academic Quality in Schools

Nursih. 2007. Influence of Principal Supervision Services and Outstanding Motivation on The Performance of Physical Education Teachers (Studies at Public Elementary Schools in Majalengka Regency. Downloaded from http://jurnal.upi.edu/106/view/1435/pengaruh--layanan-supervisikepalasekolah-dan-motivasi-berprestasi-terhadap-kinerja-guru-pendidikan- 108 physical(study-in-school-elementary-state-in-district-majalengka).html. January 13, 2015.

Sudin. Ali. 2008. Implementation of Academic Supervision of the Learning Process in Sumedang Elementary School. Downloaded from: http://jurnal.upi.edu/pendidikandasar/view/103/implementasi-supervisiakademik-terhadapproses-pembelajaran-di-sekolahdasarse-kabupatensumedang.html. January 15, 2015.

Abdul Gafur (1986). Instructional design: a systematic step of preparing the basic pattern of teaching and learning activities. Sala: Triad.

Abdul Gafur (1987). Influence of sequence delivery strategies, feedback, and intellectual skills on concept learning outcomes. Jakarta : PAU - UT.

Arifin, I. 2000. Teacher Professionalism: Analysis of Education Reform Discourse and The Era of Globalization. National Symposium on Education at the University of Muhammadiyah Malang, 25-26 July 2001.

Arikunto, Suharsimi. 1993. Education Management. Jakarta: Rineka Cipta.

2007. Class Action Research. Jakarta: PT Bumi Aksara.

Bafadal Ibrahim, 1979. Supervising Teaching Theory and Its Application in Fostering Professional Teachers, Jakarta: Rineka Cipta.

Dedi Herawan, 2005. Development of Academic Supervision Model of IPA-Biology Subjects: Effectiveness of Academic Supervision Innovation Model Of Biological IPA Subjects in An Effort to Improve the Performance of IPA Biology Teachers in SMU. Unpublished thesis upi Bandung.

Depdiknas RI,2003. Law No. 20 on the National EducationSystem. Jakarta : depdiknas.

,2005 Law No. 14 on Teachers and Lecturers. Jakarta: Depdiknas.

Director General of PMPTK, 2007. Ministerial Regulation no. 13 on Competency Standards of Madrassa Heads. Jakarata: Director General of PMPTK Depdiknas

2009. Independent Learning Materials Of Madrasah Head Working Group On Dimensions of Managerial Competence. Jakarta :D irjen PMPTK Depdiknas.

Directorate of PLP Depdiknas. 2005. School-Based Quality Improvement Management. Jakarta: Depdiknas. 